\title{
Possible Effect of Pressure Solution on the Movement of a Canister in the Buffer of Geological Disposal System
}

\author{
Koichi Shin \\ Central Research Institute of Electric Power Industry, Tokyo, Japan \\ Email:shin@criepi.denken.or.jp
}

How to cite this paper: Shin, K. (2017) Possible Effect of Pressure Solution on the Movement of a Canister in the Buffer of Geological Disposal System. International Journal of Geosciences, 8, 167-180. https://doi.org/10.4236/ijg.2017.82006

Received: December 8, 2016

Accepted: February 7, 2017

Published: February 10, 2017

Copyright $\odot 2017$ by author and Scientific Research Publishing Inc. This work is licensed under the Creative Commons Attribution International License (CC BY 4.0).

http://creativecommons.org/licenses/by/4.0/

\begin{abstract}
One of the major concepts of the geological disposal of high level radioactive waste is to enclose a metallic container with bentonite buffer which is considered to be impermeable and chemically stable. Since the average density of the container is around 6 to 7 and very heavy compared to bentonite, the scenario of container sinking has been evaluated because excess sinking makes short the pathway of nuclide migration in the bentonite and is detrimental to the safety of the disposal system. Previous considerations on container sinking have been made from the viewpoint of mechanical deformation of the bentonite. In this paper, a chemical deformation process is presented as another mechanism of container sinking, which has not been previously considered for the container sinking in the field of radioactive waste disposal. The chemical deformation mentioned in this paper is the deformation through the process of pressure solution of minerals constituting the buffer, transportation by diffusion and precipitation. That such chemical deformation is a ubiquitous phenomenon occurring in various scales in the crust of the earth will be shown through the review of previous works. Then, some future research topics will be suggested which would be required in order to evaluate the container sinking in the safety case for radioactive waste disposal.
\end{abstract}

\section{Keywords}

Safety Case, Buffer Deformation, Pressure Solution, Canister Sinking, Geological Disposal

\section{Introduction}

The foremost objective of geological disposal of long lived radioactive wastes is 
to protect humans and the environment both at present and in the future. To this end, engineered barrier is to be fabricated in a geologically favorable rock at geologically stable area. Natural and engineered barriers are aimed at limiting ground water contact with the waste and the subsequent transport of radionuclides to the biosphere. The disposal system needs to be safe for all the relevant important phenomena which can occur in the disposal system. The endeavors toward geological disposal presently being made in the world are sharing this principle to ensure the safety.

But this paper is to present a problem to be solved which has seemingly not been considered in any of the previous works on geological disposal of radioactive waste. It is the sinking of waste containers in clay bearing buffer through the deformation of the buffer by pressure solution creep (Chap. 4). Sinking itself has been evaluated in detail in previous safety assessments but only from the mechanical point of view. Another possible phenomenon of sinking through a chemical process has not been considered. In order to describe the nature of the problem clearly, a review on the pressure solution is made (Chap. 2), and some of the societal and technical efforts made so far in the world toward the safe disposal are mentioned beforehand (Chap. 3). Some ideas for future researches are added, including the advantage of using stable isotopes in Chap. 4.

In this way, this paper points out a new viewpoint which needs to be considered in safety assessment for geological disposal, suggests preliminary ideas to solve the problem and thus helps to facilitate future research works to contribute to the safety of the geological disposal.

\section{Pressure Solution}

Pressure solution is a phenomenon of enhanced dissolution of solids into aqueous solution by stresses in the solids, and it often means the resultant deformation process through dissolution and diffusion. It has been found in geological observations in as early as 1860s. Sorby has pointed out in 1865 that stylolite and impressed pebble are formed by pressure solution. Gibbs has formulated the thermodynamic chemical potential of solid as a function of temperature and stress on the surface concerning the phase equilibrium in 1877. However, pressure solution was considered as a relatively limited geological phenomenon for a long time. Referring to Japanese geological dictionaries, the one published from Shinkokinshoin in 1973 has no entry for pressure solution and suggests the cause of stylolite as partial melting. But another dictionary published from Heibonsha in 1996 includes pressure solution and explains the cause of stylolite as pressure solution as with the present understanding. In recent years, researches have been conducted not only in the field of geology but also in rock engineering and others.

The following is the review on pressure solution to show that it is an almost omnipresent phenomenon observed in the wide range of depth of the crust deeper than about $90 \mathrm{~m}$, that it is one of the important mechanisms of deformation of the crust, and so on. 


\subsection{Geological Observations}

Gratier [1] has observed outcrops of limestone at Rabat, Morocco and estimated that the volume of the rock mass has decreased by $26 \%$ through an examination of stylolite. Alvalez et al. [2] have observed cleavage and folding in a limestone at Umbria, Italy and pointed out that they have been formed through pressure solution. They also supported the suggestion of Burger [3] that pressure solution was probably much more important in rock deformation than had generally been realized. Shimizu [4] has studied the Sambagawa low-grade metamorphic rock through microstructural examination of radiolarian fossils and others and pointed out the significance of pressure solution as a deformation mechanism of the rock. Schwarz et al. [5] have observed the microstructure of phyllite and quartzite from Crete, Greece and revealed that the deformation mechanism is pressure solution and that clastic quartz grains in the phyllites show no evidence for crystal plastic deformation, and thus suggested that the effective viscosity in deep crustal levels $(30 \mathrm{~km})$ in forearc settings should be much lower than that predicted by conventional models based on flow laws for dislocation creep. Davison et al. [6] have studied the overburden deformation patterns and mechanisms of salt diapirs in the Central Graben, North Sea and pointed out that $50 \%$ of the chalk has dissolved due to pressure solution. De Meer et al. [7] have stated through an extensive literature review that pressure solution is an important mechanism for; diagenetic compaction in sedimentary rocks; healing, sealing and strength recovery in active fault zones; deformation under low temperature metamorphic conditions; and evaporite flow. Ebner et al. [8] have studied the morphology of stylolite in limestone from France and suggested that it can be considered as a quantitative stress gauge. Tada and Siever [9] have suggested that stylolite can be formed at depth as shallow as $90 \mathrm{~m}$. Wassmann et al. [10] have examined the microstructural record of serpentinites from Western Alps, using optical and scanning electron microscopy with electron backscatter diffraction (EBSD). They have found that significant deformation and high strain are not by dislocation creep but by pressure solution and suggested Newtonian behaviour and a low viscosity for the long-term flow of serpentinites in deeper levels of subduction zones. Fagereng [11] has studied the Cape Fold Belt, South Africa and suggested that pressure solution accommodates a significant component of horizontal shortening during the Cape Orogeny.

\subsection{Laboratory Experiments and Mechanism of Pressure Solution}

Sprunt et al. [12] have observed the dissolution rate around a fluid-filled circular hole in a slab loaded perpendicularly to the axis of the hole. Single crystals of halite, limestone, dolomite, marble, quartzite and novaculite were used to make the slabs. From the resultant shape of the hole they have suggested that the dissolution rate at a point is directly proportional to local stress rather than strain energy.

Concerning diagenetic compaction, Gratier and Guiget [13] used quartz grain aggregate, and Zhang and Spiers [14] used limestone aggregate in their pressure 
solution experiments. The experiments by Zhang and Spiers have been conducted at room temperature with varied grain size (1 to 100 micrometer) and stress ( 1 to $4 \mathrm{MPa}$ ) in saturated $\mathrm{CaCO}_{3}$ solution. And they have found that larger stress and smaller grain size make the deformation rate larger.

Experiments and model studies on stylolite formation have also been reported by Gratier et al. [15], Ebner et al. [16] and others.

In some experiments light interference fringe technique has been used to measure the pressure solution induced deformation accurately, where two crystals with shapes of flat and convex lenses are pressed together in a solution. Some results include that pressure solution is more noticeable between different kinds of minerals than the same ones and especially clay mineral enhances pressure solution of other minerals [17], that initial fast rate of deformation converges to a small value and this is because the mineral resolved at the contact region precipitates around like jelly [18], that the deformation rate is depending on the electric potential between the minerals [19], and so on. Ichikawa et al. [20] have conducted experiments on the effect of $\mathrm{pH}$, temperature and pressure on pressure solution between two shaped crystals of quartz.

The phenomenon of pressure solution has come to be well recognized but its mechanism is still not clear in many aspects. Studies on which of the elastic strain and the plastic strain enhances the dissolution have been reported [21] [22] [23]. Rutter [24] has studied about the contact structure of adjacent minerals undergoing pressure solution; whether they are contacting to each other directly or indirectly via very thin water layer. Hickman \& Evans [17] have reported that there are two locations of pressure solution, one is at the contact region and the other is at the free surface just around the contact region. Noort [25] has reported that crystallographic directions of minerals affect pressure solution. Takada \& Fujii [26] have paid attention to the Gibbs free energy and applied molecular dynamics to pressure solution.

\subsection{Creep of Rocksalt and Sinking of Rocks in Salt Dome}

Since rocksalt is susceptible to creep deformation even under low temperature and low stress, it exhibits unique geological phenomena such as formation of salt domes caused by the buoyancy of light salt. Urai et al. [27] have reported that experimental creep data of dry rocksalt is consistent with dislocation creep mechanism but cannot explain the deformation phenomena observed in salt dome, and that experimental creep data of wet rocksalt as in geological formations are consistent with pressure solution theory and can explain the deformation in salt dome. Campos [28] has observed extensively the creep deformation of rocksalt at a potash mine in Spain and analyzed the strain curves $\varepsilon \propto \sigma^{\mathrm{m}} \mathrm{t}^{\mathrm{n}}$, and concluded that the deformation mechanism of the rocksalt at this mine is not dislocation creep but pressure solution creep. Keken et al. [29] numerically calculated the development of a salt dome using a rheology model which depended on temperature, pressure and grain size, incorporating both mechanisms of dislocation and pressure solution creeps. And they reported that pressure solution creep 
was dominant in most of the cases, that the effect of temperature gradient was small and that the effect of grain size was large.

It is known that evaporites and other rocks are often entrained in a salt dome and carried away from distant original locations. Gansser [30] has suggested that water content is more important than temperature for the migration of rocks. Chemia et al. [31] have shown that heavier anhydrite moves up along with a rocksalt diapir formation and after the decrease of the ascending speed, turns to sinking, in a series of numerical calculation of Newtonian flow using parameters from previous experiments. Burchardt et al. [32] have numerically simulated the sinking of entrained anhydrite $\left(2.9 \mathrm{~g} / \mathrm{cm}^{3}\right)$ in the Gorleben salt diapir and pointed out that the interaction between the sinking of rocks and salt structure should be considered in a safety assessment of waste disposal facilities.

\subsection{Rock Mechanics, Radwaste Disposal and Fault Strength}

Lydzba et al. [33] have employed the pressure solution mechanism in a numerical code for simulating mechanical behavior of Chalk, because previously often employed suction mechanism has not been successful enough in explaining the mechanical behaviors of Chalk such as strength reduction and creep deformation under wet condition.

Yasuhara et al. [34] have evaluated the fluctuation of permeability during 10,000 years around a radwaste disposal facility through T-H-M-C coupling simulations taking into account the pressure solution. Parameters have been taken from quartzite data. The simulation suggested a favorable result for the safety of geological disposal because the permeability around a disposal tunnel decreased.

Implications of pressure solution on fault creep, strength recovery and permeability of fault have come to be studied in recent years. Bos and Spiers [35] have observed the change of microstructure and mechanical behavior of fault gouge containing phyllosilicates in a series of shear test, and suggested that pressure solution is the more plausible mechanism of fault displacement than the dislocation. Yasuhara et al. [36] have obtained the relations between strength recovery and interseismic period in a series of shear experiment on silica particles of diameter $0.1 \mathrm{~mm}$ at normal stress of $5 \mathrm{MPa}$ in the temperature range from 20 to 65 degree Celsius. They have also simulated the strength recovery using a numerical code employing pressure solution theory and suggested its significance in fault activities. Fagereng [37] has pointed out that granular flow, pressure solution and dislocation creep are the mechanisms of frictional slip deformation of a fault, that pressure solution mechanism exists in wide range of depth and temperature in the crust and that the pressure solution is suggested to be an important deformation mechanism in fine-grained, fractured, fluid-saturated rocks which are commonly present within fault gouge of the crustal earthquake sources. Gratier et al. [38] have observed a power law in pressure solution indenter experiments and also in post-seismic creep deformation of active faults, and suggested that monitoring the power law parameters in natural faults could give access to the characteristic healing time in the fault. Scuderi et al. [39] have 
made experiments of stick-slip of fault gouge modeled by glass beads. From the measured parameters such as stick-slip stress drop, recurrence time, dilatancy of the gouge and SEM observation of the glass beads after the experiment, they have suggested that pressure solution dictates stick-slip stress drop and interseismic creep rates and thus play a key role in earthquake nucleation and rupture propagation.

\subsection{Conclusion of the Review}

Pressure solution or the process of dissolution, diffusion and precipitation is an omnipresent phenomenon and one of the important mechanisms that has deformed the earth crust. Pressure solution occurs in wide range of temperature and depth. In laboratory, pressure solution experiments under the stress as low as around $0.1 \mathrm{MPa}$ have been conducted. And it is considered that many kinds of rock-forming minerals are susceptible to pressure solution more or less. Pressure solution of metals also has been reported [40].

\section{Efforts for Radioactive Waste Disposal}

Before discussing the possible effect of pressure solution on the sinking of a canister in the buffer of geological disposal system, societal background is briefly described to show the importance of considering the possible effect. Then previous considerations on canister movement are shortly described as the technical background.

\subsection{Societal Aspect}

Countries with nuclear power plants are making efforts for geological disposal of high level radioactive waste as the responsibility of the present generation. Some countries in Europe and the US started selecting the disposal site in 1970's and 1980's but met with oppositions from the communities and the society. In this background, ethical principles such as that the same safety level should be applied to the future generation as ours in managing the disposal of long-lived radioactive waste, have been internationally confirmed [41]. In 2004, the principle that the ground of safety of geological disposal should be described objectively with traceability in a set of documents called safety case was established [42]. IAEA [43] has issued a safety standard on the safety case for the geological disposal and prescribed that every phenomenon and process that could significantly influence the performance of disposal system should be addressed in the assessment. Through these efforts to ensure the safety, public understanding has begun to be gained and application of construction has been submitted in 2011 in Sweden and 2012 in Finland. In Japan, the submission is not yet made and efforts are being undertaken [44] [45].

\subsection{Technical Aspect-Container Movement}

For the assessment of the safety of geological disposal, long-term stability of geological environment and performance of engineered barrier are the impor- 
tant part of the evaluation. Among various types of engineered barrier, Sweden and Japan for example have been considering a type in which waste bearing container is wrapped by a buffer containing low permeability bentonite to suppress the contact of the metal container with the underground water. The anticipated functions of the buffer are to prevent the contact of radioactive waste with underground water for long period by deterring the corrosion of metal container, to delay the migration of radionuclide solution after the container is damaged, and to suppress the migration of radionuclide by adsorbing it. To ensure these functions, it is necessary to prevent excessive sinking of the heavy container in the buffer because too small thickness of the buffer deteriorates the functions. Therefore the sinking of container has been quantitatively evaluated in those countries from mechanical points of view. In Sweden, the regulatory authority has designated the movement of canister in the buffer as a process that can affect the performance of a disposal system [46]. SKB, the implementer of geological disposal in Sweden, has evaluated the sinking through mechanical considerations onto the buffer, and concluded that the sinking during 100,000 years is very small [47]. In Japan, container movement has been numerically analyzed using a visco-elasto plastic model for the buffer's constitutive law, and the sinking of container has been concluded to be as small as $5 \mathrm{~mm}$ after 10,000 years and thus be negligible [44].

From the results mentioned above, it seems worldwide general perception is that container movement does not pose a serious problem if the engineered barrier is adequately designed. In contrast, a public comment was posted to a Japanese governmental committee on geological disposal in 2013 that sinking of a container could be significant in a geologically long period. But the discussion did not go further and virtually no consideration on another possible mechanism of sinking has been made so far.

In the following, the author points out that chemical process (dissolution and diffusion) exists besides the mechanical process that can cause a container to sink in the buffer. And he describes the reason that chemical sinking should never be neglected, by referring to previous works in other fields, although detailed knowledge required for quantitative evaluation of the sinking is nonexistent yet.

\section{Sinking of a Container Due to Pressure Solution}

\subsection{The Process}

As a geological phenomenon in the shallow crust, sinking of rocks entrained in a salt dome is often observed. Dislocation creep and pressure solution creep have been pointed out as the mechanisms of salt deformation, and the pressure solution creep is predominant at low temperature and pressure in wet condition. Although the description of the detailed mechanism of sinking of rocks in a salt dome has not been found in the review, the conceptual mechanism of sinking of heavy objects is easily conceived with the notion of pressure solution. At the undersurface of a heavy object, larger stress on rocksalt enhances the dissolution 
and salt concentration in the pore water increases. The dissolved salt migrates by diffusion to a less stressed region due to the concentration gradient and precipitates. Through this process of mass transfer, heavy things sink gradually.

This sinking process is conceptually shown in Figure 1 in the case of the sinking of a container in the buffer. The average density of a container for vertical disposal type is, referring to the design concepts in Sweden and Japan, around $6.5 \mathrm{~g} / \mathrm{cm}^{3}$. Supposing the density of the buffer to be $2 \mathrm{~g} / \mathrm{cm}^{3}$, the stress increments due to the container weight are about $0.1 \mathrm{MPa}$ and 0.2 $\mathrm{MPa}$ for the Japanese and Swedish cases respectively. Since the stress increment is small, the sinking rate caused by the mechanism shown in Figure 1 may be small, but presently we do not have a detailed mechanism model and data that would be necessary for quantitative evaluation of the sinking.

\subsection{Sinking Rate}

As mentioned above, it is difficult at present to estimate the sinking velocity of a container. Therefore a rough surmise is made here by referring to previous studies made from various points of view concerning pressure solution, whether the sinking rate of a container can be neglected or not. But the author would like to stress that regardless of the surmise, convincing evaluation should be made in a safety assessment of a disposal system in the future by clarifying the detailed mechanism and obtaining relevant data.

In the experiment by Hickman and Evans [17], the minimum convergence rate of $0.01 \mu \mathrm{m} /$ day has been observed at 8 degree Celsius and contact stress 0.5 $\mathrm{MPa}$, for the pressure solution at a single contact between a halite crystal and a fused quartz plate. When many contacts are serially superimposed as in the case of soil or aggregate, the rate will increase accordingly. The experiment of pressure solution at a single contact by Greene et al. [19] was made for the combination of mica-mica, quartz-quartz and mica-quartz. The contact stress was 0.2 to
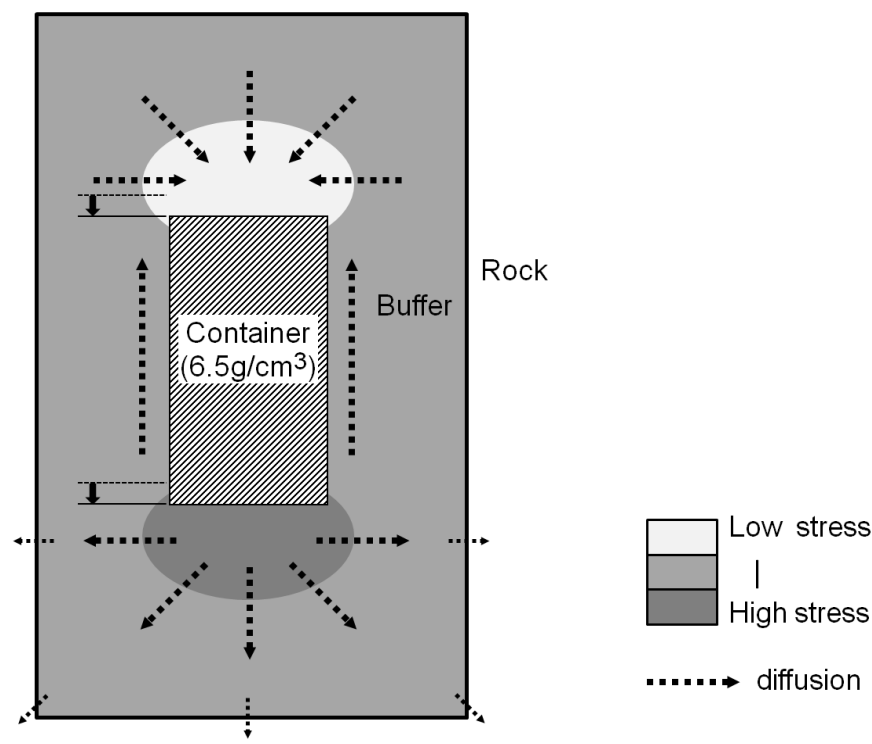

Figure 1. Conceptual process of container sinking. 
$0.3 \mathrm{MPa}$ and temperature was 25 degree Celsius. The convergence rate was the largest in the case of mica-quartz, $4 \mathrm{~nm} / \mathrm{min}$ initially and $0.01 \mathrm{~nm} / \mathrm{min}$ at the stationary state. In the experiment of diagenetic compaction of calcite aggregate by Zhang and Spiers [14], strain rate of $8 \times 10^{-5} /$ day is read for the stationary state at stress $1 \mathrm{MPa}$. Deformation rate of $9.6 \times 10^{-7} \mathrm{~m} /$ day is obtained from the length of the aggregate specimen $1.2 \mathrm{~cm}$. When the length increases, so does the deformation rate linearly. In the study of horizontal shortening of the Cape Fold Belt by Fagereng [11], pressure solution-induced strain rate of $10^{-14}$ to $10^{-15} / \mathrm{s}$ is suggested. This is converted to 0.03 to $0.3 / \mathrm{Ma}$. In numerical calculations of sinking of anhydrite in a salt dome by Burchardt et al. [32], the minimum sinking rate is $1600 \mathrm{~m} / \mathrm{Ma}$. Seni and Jackson [48] have compiled data on the history of salt dome development in the East Texas Basin and pointed out that the rate of upward growth of domes ranges from 150 to $530 \mathrm{~m} / \mathrm{Ma}$ at the peak stage of development.

The six evaluations mentioned above are listed in Table 1. These are based on different kinds of laboratory experiments, geologic observations and simulations of sinking of a rock in a salt dome. They include deformation rate with the unit $\mathrm{m} / \mathrm{Ma}$ and strain rate with the unit 1/Ma. Experimental conditions are also quite different, and some of the stresses are nominal and others are real contact stresses. Therefore these data are not quantitatively comparable to each other, nor valid for quantitative estimation of the sinking velocity of a container in the buffer. Nevertheless, considering that initial widths of the buffer below the container are 0.5 and $0.7 \mathrm{~m}$ for Japanese and Swedish designs of engineered barrier respectively, the data in Table 1 suggest that the sinking velocity of a container can be significant in a geological time scale comparable to the safety assessment period. Thus the sinking by the process of chemical deformation or pressure solution of the buffer material needs to be evaluated in detail in a safety case of a geological disposal.

Table 1. Rate of deformation by pressure solution from various sources.

\begin{tabular}{|c|c|c|c|c|c|}
\hline & & Description & \multicolumn{2}{|c|}{ Rate (unit) } & remarks \\
\hline 1 & \multirow{3}{*}{$\begin{array}{l}\text { Laboratory } \\
\text { experiment }\end{array}$} & $\begin{array}{l}\text { single contact, } 0.5 \mathrm{MPa}, 8^{\circ} \mathrm{C} \\
\text { (halite-fused silica) }\end{array}$ & $>3.65$ & $\mathrm{~m} / \mathrm{Ma}$ & $\begin{array}{l}\text { 0.01 micro m/day, Fig. } 17 \text { A in } \\
\text { (Hickman \& Evans, 1995) }\end{array}$ \\
\hline 2 & & $\begin{array}{c}\text { Single contact, } 0.2 \mathrm{MPa}, 25^{\circ} \mathrm{C} \text {, } \\
\text { (quartz-mica) }\end{array}$ & 5 & $\mathrm{~m} / \mathrm{Ma}$ & $\begin{array}{l}0.01 \mathrm{~nm} / \mathrm{min}, \text { Abstract of } \\
\quad(\text { Greene et al., 2009) }\end{array}$ \\
\hline 3 & & $\begin{array}{l}\text { Aggregate of calcite, } \\
1 \mathrm{MPa} \text {, room temp. }\end{array}$ & $>350$ & $\mathrm{~m} / \mathrm{Ma}$ & $\begin{array}{c}0.16 \% / 20 \text { days, } \mathrm{L}_{0}=1.2 \mathrm{~cm} \text {, Fig. } 4 \text { in } \\
\text { (Zhang \& Spiers, 2005) }\end{array}$ \\
\hline 4 & \multirow[b]{2}{*}{ Salt dome } & $\begin{array}{l}\text { Anhydrite sinking in saltdome } \\
\text { (numerical calculation) }\end{array}$ & 1600 & $\mathrm{~m} / \mathrm{Ma}$ & $\begin{array}{l}\text { case } 1: 1 \text { of series A, Fig. } 11 \text { in } \\
\text { (Burchardt et al., 2012) }\end{array}$ \\
\hline 5 & & $\begin{array}{l}\text { Salt dome development, } \\
\text { East Texas Basin, US }\end{array}$ & $150-530$ & $\mathrm{~m} / \mathrm{Ma}$ & Abstract in (Seni \& Jackson, 1984) \\
\hline 6 & Folding & Cape fold belt, SA & $0.03-0.3$ & $1 / \mathrm{Ma}$ & $\begin{array}{l}\text { strain rate: } 1 \mathrm{E}-15 \text { to } 1 \mathrm{E}-14(1 / \mathrm{s}) \\
\text { Conclution of (Fagereng, 2014) }\end{array}$ \\
\hline
\end{tabular}




\subsection{Ideas for Future Evaluation}

From the considerations mentioned so far, it can be said that a process of container sinking caused by pressure solution certainly exists. In the assessment of geological disposal, a judgment should be made whether the sinking rate is negligible for the safety assessment period or not. If it cannot be neglected, some adjustments to the design of engineered barrier or other measures are required. But present scientific knowledge is not enough for the present generation to make a judgment.

Some of the ideas the author thinks important for the evaluation of container sinking through pressure solution are listed to facilitate the future study.

1) The buffer is considered to be bentonite or the mixture of bentonite and quartz sand. Bentonite itself contains montmorillonite and fine silica particles. It has been observed in laboratory experiments and geologic phenomena that clay minerals enhance the pressure solution of quartz considerably. So the pressure solution between montmorillonite and quartz is considered to be the first target.

2) Some experiments have shown electrical aspects of pressure solution. This is plausible because dissolution and precipitation of minerals involve ion transportation. Since containers are made of metal, the movement of electron between the solution site at the bottom and the precipitation site at the top of a container is facile and hence the solution may be accelerated. Studies on the detailed process including this viewpoint are desirable.

3) Elastic strain on a mineral surface changes the relative locations of cations and anions constituting the mineral and causes a change of electric potential on the surface and affects the dissolution. This may be one of the physical backgrounds of pressure solution.

4) Since the rate of container sinking will be controlled by the slower process between dissolution and diffusion, the study on diffusion process will also be important as on dissolution.

5) It is considered very difficult to measure chemical deformation of the buffer material directly in experiments because mechanical deformation is considered to be far larger. Experiments using stable isotopes such as ${ }^{29} \mathrm{Si}$ and ${ }^{30} \mathrm{Si}$ could be helpful to distinguish chemical deformation from mechanical one.

The process of evaluating the pressure solution facilitated container sinking includes the following steps: 1 ) observation/confirmation of the phenomenon; 2) evaluation of dissolution/diffusion rates; 3 ) numerical modeling of sinking process and evaluation of sinking rate. To contribute to these steps; 4) clarification of physical mechanism of pressure solution, is also important.

Among various methods we may be able to think of for evaluating the pressure solution facilitated container sinking, a primitive experimental idea is presented here. The buffer material made from montmorillonite and silica powder should be partially loaded by a rod in a wet condition. The rod may be penetrated to the half depth of the buffer specimen. Buffer material containing $\mathrm{SiO}_{2}$ made from $\mathrm{Si}$ isotopes is placed on the undersurface of the rod beforehand as a tracer. In this way the transportation of the dissolved silica can be traced and 
thus the phenomenon can be observed. Some knowledge about the effect of load, temperature and chemical composition of the pore water will also be obtained. By comparing the results of experiments using conductive and nonconductive rods, effects of electric aspects of pressure solution will also be observed.

\section{Concluding Remarks}

The disposal of existing radioactive waste is the responsibility of the present generation regardless whether we will rely on nuclear power generation or not. The international community of nuclear power nations has, with a lesson of incipient failures in site selections for geological disposal in mind, established a principle that the implementer of geological disposal should present the safety of the disposal system objectively, transparently and traceably to the society.

Although the problem of container sinking through a chemical process has been brought up after that, it needs to be dealt with duly in a safety assessment. But presently the scientific knowledge about it is quite lacking. In order that geological disposal might progress steadily backed by the public understanding, that the risk of retrieving the containers after disposal due to the concern of the problem might be avoided, and that we might not feel shame toward the future generation for not evaluating an important possible scenario of the evolution of the disposal system, it is hoped that progress is made in researches on the clarification of the detailed mechanism, acquisition of relevant data, and so on.

\section{References}

[1] Gratier, J.P. (1976) Déformation et changement de volume dans un marbre à stylolithes de la région de Rabat (Maroc). Bulletin de la Société géologique de France, 7, 1461-1469. https://doi.org/10.2113/gssgfbull.S7-XVIII.6.1461

[2] Alvarez, W., Engelder, T. and Lowrie, W. (1976) Formation of Spaced Cleavage and Folds in Brittle Limestone by Dissolution. Geology, 4, 698-701.

https://doi.org/10.1130/0091-7613(1976)4<698:FOSCAF>2.0.CO;2

[3] Burger, H.R. (1974) Pressure-Solution: How Important a Role? Geological Society of America Abstracts with Programs, 6, 1026-1027.

[4] Shimizu, I. (1988) Ductile Deformation in the Low-Grade Part of the Sambagawa Metamorphic Belt in the Northern Kanto Mountains, Central Japan. Journal of the Geological Society of Japan, 94, 609-628. https://doi.org/10.5575/geosoc.94.609

[5] Schwarz, S. and Stockhert B. (1996) Pressure Solution in Siliciclastic HP-LT Metamorphic Rocks-Constraints on the State of Stress in Deep Levels of Accretionary Complexes. Tectonophysics, 255, 203-209.

https://doi.org/10.1016/0040-1951(95)00137-9

[6] Davison, I., Alsop, G.I., Evans, N.G. and Safaricz, M. (2000) Overburden Deformation Patterns and Mechanisms of Salt Diapir Penetration in the Central Graben, North Sea. Marine and Petroleum Geology, 17, 601-618.

https://doi.org/10.1016/S0264-8172(00)00011-8

[7] De Meer, S., Drury, M.R., De Bresser, J.H.P. and Pennock, G.M. (2002) Current Issues and New Developments in Deformation Mechanisms, Rheology and Tectonics. Geological Society, London, Special Publications, Vol. 200, 1-27. https://doi.org/10.1144/GSL.SP.2001.200.01.01

[8] Ebner, M., Toussaint, R., Renard, F. and Schmittbuhl, J. (2009) Stress Sensitivity of 
Stylolite Morphology. Earth and Planetary Science Letters, 277, 394-398.

https://doi.org/10.1016/j.epsl.2008.11.001

[9] Tada, R. and Siever, R. (1989) Pressure Solution during Diagenesis. Annual Review of Earth and Planetary Sciences, 17, 89-118. https://doi.org/10.1146/annurev.ea.17.050189.000513

[10] Wassmann, S., Stöckhert, B. and Trepmann, C.A. (2011) Dissolution Precipitation Creep versus Crystalline Plasticity in High-Pressure Metamorphic Serpentinites. Geological Society, London, Special Publications, Vol. 360, 129-149. https://doi.org/10.1144/SP360.8

[11] Fagereng, A. (2014) Significant Shortening by Pressure Solution Creep in the Dwyka diamictite, Cape Fold Belt, South Africa. Journal of African Earth Sciences, 97, 918. https://doi.org/10.1016/j.jafrearsci.2014.04.022

[12] Sprunt, E.S. and Nur, A. (1977) Experimental Study of the Effects of Stress on Solution Rate. Journal of Geophysical Research, 82, 3013-3032. https://doi.org/10.1029/JB082i020p03013

[13] Gratier, J.P. and Guiget, R. (1986) Experimental Pressure Solution Deposition on Quartz Grains: The Crucial Effect of the Nature of the Fluid. Journal of Structural Geology, 8, 845-856. https://doi.org/10.1016/0191-8141(86)90030-1

[14] Zhang, X. and Spiers, C.J. (2005) Compaction of Granular Calcite by Pressure Solution at Room Temperature and Effects of Pore Fluid Chemistry. International Journal of Rock Mechanics and Mining Sciences, 42, 950-960. https://doi.org/10.1016/j.ijrmms.2005.05.017

[15] Gratier, J.P., Muquet, L., Hassani, R. and Renard, F. (2005) Experimental Microstylolites in Quartz and Modeled Application to Natural Stylolitic Structures. Journal of Structural Geology, 27, 89-100. https://doi.org/10.1016/j.jsg.2004.05.007

[16] Ebner, M.J. (2009) The Development of Stylolites, from Small-Scale Heterogeneities to Multi-Scale Roughness. Doctoral Thesis, Johannes Gutenberg-Universitat, Mainz.

[17] Hickman, S.H. and Evans, B. (1995) Kinetics of Pressure Solution at Halite-Silica Interfaces and Intergranular Clay Films. Journal of Geophysical Research, 100, 13113 13132. https://doi.org/10.1029/95JB00911

[18] Meyer, E.E., Greene, G.W., Alcantar, N.A., Israelachvili, J.N. and Boles, J.R. (2006) Experimental Investigation of the Dissolution of Quartz by a Muscovite Mica Surface: Implications for Pressure Solution. Journal of Geophysical Research, 111, B08202. https://doi.org/10.1029/2005jb004010

[19] Greene, G.W., Kristiansen, K., Meyer, E.E., Boles, J.R. and Israelachvili, J.N. (2009) Role of Electrochemical Reactions in Pressure Solution. Geochimica et Cosmochimica Acta, 73, 2862-2874. https://doi.org/10.1016/j.gca.2009.02.012

[20] Ichikawa, Y., Tanno, T., Hikima, R., Sanada, H., Matsui, H. and Sato, T. (2012) Theoretical Study of Rock for Estimating Long-Term Behavior (FY2010). JAEAResearch 2012-003, 9-23. (In Japanese)

[21] Bosworth, W. (1981) Strain-Induced Preferential Dissolution of Halite. Tectonophysics, 78, 509-525. https://doi.org/10.1016/0040-1951(81)90026-3

[22] Morel, J. (2000) Experimental Investigation into the Effect of Stress on Dissolution and Growth of Very Soluble Brittle Salts in Aqueous Solution. Doctoral Thesis, Johannes Gutenberg-Universität, Mainz.

[23] Van Noort, R. and Spiers, C.J. (2009) Kinetic Effects of Microscale Plasticity at Grain Boundaries during Pressure Solution. Journal of Geophysical Research, 114, B03206. https://doi.org/10.1029/2008JB005634 
[24] Rutter, E.H. (1983) Pressure Solution in Nature, Theory and Experiment. Journal of the Geological Society, 140, 725-740.

[25] Van Noort, R., Spiers, C.J. and Peach, C.J. (2007) Effects of Orientation on the Diffusive Properties of Fluid-Filled Grain Boundaries during Pressure Solution. Physics and Chemistry of Minerals, 34, 95-112. https://doi.org/10.1007/s00269-006-0131-9

[26] Takada, M. and Fujii, Y. (2010) Molecular Dynamics Study Concerning Free Surface Dissolution of $\mathrm{NaCl}$ Crystal under Stress. Journal of MMIJ, 126, 72-77. (In Japanese)

[27] Urai, J.L., Spiers, C.J., Zwart, H.J. and Lister, G.S. (1986) Weakening of Rock Salt by Water during Long-Term Creep. Nature, 324, 554-557.

https://doi.org/10.1038/324554a0

[28] Campos de Orellana, A.J. (1996) Pressure Solution Creep and Non-Associated Plasticity in the Mechanical Behavior of Potash Mine Openings. International Journal of Rock Mechanics and Mining Science \& Geomechanics Abstracts, 33, 347-370. https://doi.org/10.1016/0148-9062(95)00075-5

[29] Van Keken, P.E., Spiers, C.J., van den Berg A.P. and Muyzert, E.J. (1993) The Effective Viscosity of Rocksalt: Implementation of Steady-State Creep Laws in Numerical Models of Salt Diapirism. Tectonophys, 225, 457-476. https://doi.org/10.1016/0040-1951(93)90310-G

[30] Gansser, A. (1992) The Enigma of the Persian Salt Dome Inclusions. Eclogae Geologicae Helvetiae, 85, 825-846.

[31] Chemia, Z., Koyi, H. and Schmeling, H. (2008) Numerical Modelling of Rise and Fall of a Dense Layer in Salt Diapirs. Geophysical Journal International, 172, 798816. https://doi.org/10.1111/j.1365-246X.2007.03661.x

[32] Burchardt, S., Koyi, H., Schmeling, H. and Fuchs, L. (2012) Sinking of Anhydrite Blocks within a Newtonian Salt Diapir: Modelling the Influence of Block Aspect Ratio and Salt Stratification. Geophysical Journal International, 188, 763-778. https://doi.org/10.1111/j.1365-246X.2011.05290.x

[33] Lydzba, D., Pietruszczak, S. and Shao, J.F. (2007) Intergranular Pressure Solution in Chalk: A Multiscale Approach. Computers and Geotechnics, 34, 291-305. https://doi.org/10.1016/j.compgeo.2007.02.002

[34] Yasuhara, H., Kinoshita, N., Ogata, S., Cheon, D.S. and Kishida, K. (2016) Coupled Thermo-Hydro-Mechanical-Chemical Modeling by Incorporating Pressure Solution for Estimating the Evolution of Rock Permeability. International Journal of Rock Mechanics and Mining Sciences, 86, 104-114. https://doi.org/10.1016/j.ijrmms.2016.03.015

[35] Bos, B. and Spiers, C.J. (2001) Experimental Investigation into the Microstructural and Mechanical Evolution of Phyllosilicate-Bearing Fault Rock under Conditions Favouring Pressure Solution. Journal of Structural Geology, 23, 1187-1202. https://doi.org/10.1016/S0191-8141(00)00184-X

[36] Yasuhara, H., Marone, C. and Elsworth, D. (2005) Fault Zone Restrengthening and Frictional Healing: The Role of Pressure Solution. Journal of Geophysical Research, 110, B06310. https://doi.org/10.1029/2004jb003327

[37] Fagereng, A. and Toy, V.G. (2011) Geology of the Earthquake Source: An Introduction from Geology of the Earthquake Source: A Volume in Honour of Rick Sibson. Geological Society, London, Special Publications, 359, 1-16. https://doi.org/10.1144/SP359.1

[38] Gratier, J.P., Renard, F. and Vial, B. (2014) Postseismic Pressure Solution Creep: Evidence and Time-Dependent Change from Dynamic Indenting Experiments. Journal of Geophysical Research: Solid Earth, 119, 2764-2779. 
https://doi.org/10.1002/2013JB010768

[39] Scuderi, M.M., Carpenter, B.M., Johnson, P.A. and Marone, C. (2015) Poromechanics of Stick-Slip Frictional Sliding and Strength Recovery on Tectonic Faults. Journal of Geophysical Research: Solid Earth, 120, 6895-6912. https://doi.org/10.1002/2015jb011983

[40] Parthasarathy, P. and Virkar, A.V. (2011) Effect of Stress on Dissolution/Precipitation of Platinum: Implications Concerning Core-Shell Catalysts and Cathode Degradation in Proton Exchange Membrane Fuel Cells. Journal of Power Sources, 196, 9204-9212. https://doi.org/10.1016/j.jpowsour.2011.07.027

[41] NEA (1995) The Environmental and Ethical Basis of the Geological Disposal of Long-Lived Radioactive Waste.

[42] NEA (2004) Post-Closure Safety Case for Geological Repositories-Nature and Purpose. NEA No. 3679.

[43] IAEA (2012) The Safety Case and Safety Assessment for the Disposal of Radioactive Waste. No. SSG-23. (Clause 5.42)

[44] JNC (2000) H12: Project to Establish the Scientific and Technical Basis for HLW Disposal in Japan, Supporting Report 2, Repository Design and Engineering Technology. JNC TN1410 2000-003, D38-D42.

[45] NUMO (2013) Enhancement of the Methodology of Repository Design and PostClosure Performance Assessment for Preliminary Investigation Stage (2). NUMOTR-13-06. (In Japanese)

[46] SKI (2002) Encyclopaedia of Features, Events and Processes (FEPs) for the Swedish SFR and Spent Fuel Repositories, Preliminary Version. SKI Report 02:35, 297.

[47] SKB (2011) Long-Term Safety for the Final Repository for Spent Nuclear Fuel at Forsmark. Main Report of the SR-Site Project, Vol. 1, 2, 3, SKB TR-11-01, 383-384.

[48] Seni, S.J. and Jackson, M.P.A. (1984) Sedimentary Record of Cretaceous and Tertiary Salt Movement, East Texas Basin-Times, Rates, and Volume of Salt Flow and Their Implications for Nuclear Waste Isolation and Petroleum Exploration. Report of Investigations No. 139, Bureau of Economic Geology, The University of Texas, Austin.

\section{Scientific Research Publishing}

Submit or recommend next manuscript to SCIRP and we will provide best service for you:

Accepting pre-submission inquiries through Email, Facebook, LinkedIn, Twitter, etc. A wide selection of journals (inclusive of 9 subjects, more than 200 journals)

Providing 24-hour high-quality service

User-friendly online submission system

Fair and swift peer-review system

Efficient typesetting and proofreading procedure

Display of the result of downloads and visits, as well as the number of cited articles

Maximum dissemination of your research work

Submit your manuscript at: http://papersubmission.scirp.org/

Or contact ijg@scirp.org 